\title{
Chemical Studies on Tobacco Smoke IV. The Quantitative Determination of Free Nonvolatile Fatty Acldo in Tobaceo and Tobaceo Smoke*
}

by D. Hoffmann and H. Woziwodzki

Division of Environmental Cancerigenesis, Sloan-Kettering Institute for Cancer Research,

New York, New York, USA

Bioassays have demonstrated a statistically significant tumor promoting activity for the acidic fractions of cigarette smoke condensate (21). Thus, quantitative analytic determinations of the active constituents of these fractions appeared desirable for comparisons as well as for the planning of future bioassays. Available analytical data for free fatty acids in tobacco smoke cannot be regarded as quantitative (22). However, qualitative and semi-qualitative investigations have been reported for tobacco and mainstream smoke from cigarettes and cigars.

Carruthers and Johnstone were among the first to analyze tobacco for free nonvolatile fatty acids (2). They reported in flue-cured British cigarette tobacco the presence of all fatty acids between $C_{10}-C_{26}$ with palmitic acid as major saturated component and linolenic acid as major unsaturated compound.

Swain and Stedman published semi-quantitative data for three saturated and three unsaturated fatty acids in samples of the four major types of cigarette tobaccos, a fire-cured tobacco and two cigar tobaccos (14). Palmitic acid, the major saturated fatty acid, varied between 32 and $103 \mathrm{mg}$ per $100 \mathrm{~g}$ tobacco; linolenic acid, the major unsaturated acid, amounted to as much as $111 \mathrm{mg}$ per $100 \mathrm{~g}$ tobacco. The total acid content ranged from $67 \mathrm{mg} / 100 \mathrm{~g}$ for a cigar filler to $300 \mathrm{mg} /$ $100 \mathrm{~g}$ for one variety of Bright tobacco.

Mold and his co-workers explored in detail the qualitative composition of free and combined higher fatty acids in a Bright tobacco (8). These investigators reported $76 \%$ of the total acids to be relatively non-polar saturated and olefinic types, with palmitic acid constituting $20.7 \%$ and linolenic acid $26.2 \%$. Ninety percent of the total acids were shown to have unbranched structures of 10 to 34 carbon atoms. The branched structures consisted of methyl isomers or cyclohexyl substituted compounds.

The smoke of a cigarette tobacco blend was reported to contain fatty acids between $C_{12}$ and $C_{18}$ with trace amounts of acids up to $C_{27}$ according to a study by Van Duuren and Kosak (16). About two-thirds of the fatty acids were identified as $\mathrm{C}_{16}$-acids. Clemo found saturated and unsaturated acids from $C_{8}$ to $C_{26}$ in the smoke of British cigarettes (3). Schmeltz and Schlotzhauer arrived at values of less than $20 \mu \mathrm{g}$ palmitic acid for $100 \mathrm{~g}$ cigar tobacco smoked (13); this quantity has to be

- Parts of this investigation were presented at the 20th Tobacco Chemists'Research Conference, Winston-Salem, North Carolina, November $1-3,1966$ This study was supported by American Cancer Society Grant E-231 and in part by NCI Grant CA-08748. 
regarded as extremely low. The finding of nonvolatile fatty acids with mostly eleven to sixteen carbon atoms and some with $\mathrm{C}_{17}$ and higher numbers was reported by Mohnachev et al. for the smoke of cigarettes made from oriental type tobaccos in Bulgaria (7).

So far the most detailed data on free and combined nonvolatile fatty acids in tobacco and tobacco smoke were presented by Bellin (1). They included values from the cigarette smoke from fluecured and Burley tobaccos for 9 saturated and unsaturated fatty acids between $C_{12}$ and $C_{18}$. These acids constitute between 4.5 and $5.9 \%$ of the weight of smoke condensate. The transfer rate of nonvolatile fatty acids from tobacco into the smoke was found to vary between $24-26 \%$ for flue-cured tobacco and 32-49\% for Burley tobacco.

The present investigation purported to develop a method for the quantitative determination of saturated and unsaturated nonvolatile fatty acids in tobacco and tobacco smoke, which would require not more than 10 to $20 \mathrm{mg}$ of starting material.

\section{EXPERIMENTAL}

\section{A. Reagents and Instruments}

The organic solvents used were of spectrograde quality (Matheson, Coleman \& Bell, East Rutherford, New Jersey) or commercial grade chemicals purified according to Weißberger et al. (18). n-Hexane and benzene were dried over calcium chloride. Stearic acid-1-C ${ }^{14}$ (74,900 d.p.m./ug.; International Chemical Nuclear Corporation, City of Industry, California) served as an internal

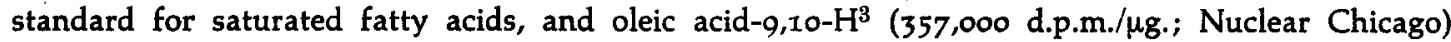
for unsaturated fatty acids. The radioactive tracers were purified via their methyl esters. The Nuclear Chicago Scintillation System 720 was used as counting equipment. It has a maximum counting efficiency for $\beta$-radiation from $\mathrm{C}^{14}$ of about $75 \%$ and from $\mathrm{H}^{3}$ of about $25 \%$. The scintillator solution was prepared by dissolving $0.4 \%$ PPO (2,5-diphenyl-oxazole) and $0.005 \%$ POPOP ( $\mathrm{p}$-bis [2-(5-phenyloxazolyl)]-benzene; Nuclear Chicago) in toluene.

Freshly distilled diazomethane (12), $\mathrm{BF}_{3}(6)$ and 2,2-dimethoxypropane (DMP; $\mathrm{K} \& \mathrm{~K}$ Laboratories, Plainview, New York) were used for the methylation of free fatty acids (10). The methyl esters were concentrated by chromatography on Florisil (Fisher Chem.). The final separation was achieved with $12 \%$ D.E.G.S. (diethylene glycol succinate; Applied Science Laboratories, State College, Pa.) on Gas Chrom P (60-80 mesh) as support in 2.5 meter stainless steel columns with an i. d. of $3 \mathrm{~mm}$ in the Wilkens Instrument 1525 gas chromatograph with a flame ionization detector (Varian Assoc., Walnut Creek, Cal.).

The dried tobacco varieties to be tested were powdered and then sieved to yield a uniform particle size of about 50 mesh. The reference compounds, methyl esters of fatty acids, were obtained from the Hormel Institute (Austin, Minnesota) and the Applied Science Laboratories. The cigarettes were smoked on a CSM-10 Automatic Machine from Cigarette Components Ltd. (19) under standardized conditions of one 2-second puff per minute with a volume of $35 \mathrm{ml}$; the chosen butt length was $23 \mathrm{~mm}(20)$.

The $85-\mathrm{mm}$ nonfilter cigarettes were made exclusively from Bright, Turkish, Maryland, and Burley tobaccos. As an additional sample, we tested an $85-\mathrm{mm}$ United States blended cigarette also without filter tip. The cigarettes were humidified for 24 hours at $58 \%$ R.H. and $21^{\circ} \mathrm{C}$. For each analysis, 10 cigarettes within $\pm 20 \mathrm{mg}$ of the average weight of 200 cigarettes were selected. The particulate matter (TPM) was collected on Cambridge filters (17). An additional trap cooled by dry ice-acetone was placed between the Cambridge filter assembly and smoking machine in order to facilitate quantitative work.

\section{B. Analysis of Fatty Acids in Tobacco}

In order to ascertain quantitative extractions of the fatty acids from tobacco yet to avoid hydrolysis of their esters, we tested the solvents n-hexane, benzene, and benzene:ethanol 4:1. As will be discussed later, benzene was found to be the most appropriate system.

The fatty acid analysis was accomplished as follows: five to ten grams of powdered tobacco 
mixture (moisture content below $I \%$ ) and a suitable small quantity of stearic acid-1- $\mathrm{C}^{14}$ and of oleic acid-9,10- $\mathrm{H}^{3}$ were placed in a thimble, covered with prewashed cotton ${ }^{*}$ and subjected to soxhlet extraction with dried benzene for 24 hours. After three washings with benzene all solvent was evaporated under reduced pressure. The residues of Turkish and Bright tobaccos were green oils, those of the other tobaccos were yellow semi-solids. The residue was dissolved in $30 \mathrm{ml}$ of ether and was then extracted with three $30 \mathrm{ml}$ portions of $2 \mathrm{~N} \mathrm{KOH}$. Thereafter, the ether layer was washed once with $15 \mathrm{ml}$ of water, all $\mathrm{KOH}$ and aqueous layers were combined, and were acidified with $5 \mathrm{~N} \mathrm{HCl}$ while being cooled in an ice-bath. The free acids were extracted from this solution with three equal volumes of ether. The combined ether layers were dried over anhydrous sodium sulfate, filtered, and evaporated.

Fifty $\mathrm{mg}$ of the extracted acids were placed into a flask together with $2 \mathrm{ml}$ methanol, $0.2 \mathrm{ml}$ $5 \mathrm{~N} \mathrm{HCl}$ and $5 \mathrm{ml} \mathrm{DMP}$. After standing at room temperature for one hour, the admixture was transferred with toluene into a round bottom flask, and the solvent was evaporated under reduced pressure. The residual crude ester-fraction was placed onto a Florisil column $(1.5 \times 8 \mathrm{~cm})$ and eluted with $250 \mathrm{ml}$ hexane:benzene (1:1) and, subsequently, with $50 \mathrm{ml}$ benzene. The solvents were evaporated and the residue was transferred with small volumes of toluene into a $1 \mathrm{ml}$ volumetric flask. Aliquots of this solution were used for counting of the $\mathrm{C}^{14}$ and $\mathrm{H}^{3}$ activities and for the gas chromatographic separation of the esters.

About $1 / 10$ aliquots were injected into the $20 \mathrm{ml}$ vials with scintillator solution, which were then counted in $\mathrm{C}^{14}$ and $\mathrm{H}^{3}$ settings. The observed quenching effects of the ester admixture were within the experimental deviation and could be neglected.

Another aliquot of the methyl ester concentrate was separated by gas chromatography (see part A). The temperatures were $265-300^{\circ} \mathrm{C}$ at the injection port, $275^{\circ} \mathrm{C}$ at the detector. Programming was initially $140^{\circ} \mathrm{C}, 10$ minutes isothermal, then progressive heating at a rate of $4^{\circ} \mathrm{C}$ per minute until $200^{\circ} \mathrm{C}$ was reached. Helium was used as carrier gas with an inlet pressure of $4.2 \mathrm{~atm}$. (60 $\left.\mathrm{lbs} \mathrm{in}^{2}\right)$ and a flowrate of $55 \mathrm{ml}$ per minute. The above described method can be applied on a microscale for the analysis of the five major fatty acids with as little as 10-20 $\mathrm{mg}$ of tobacco as starting material.

Fatty acid esters are present in tobacco as well as in smoke condensates (22). In order to control their hydrolysis during the analytical procedures, we added purified methyl oleate carboxyl- $\mathrm{C}^{14}$ (1,100 d.p.m./ug.; Tracerlab, Waltham, Massachusetts) at the beginning of an analysis. Extracts and acidic portions were then examined for $\beta$-activity.

\section{Identification of Nonvolatile Acids}

For an identification of the maxima in the chromatograms, in addition to the retention times, the effluents from the column were split at a ratio $1: 3$ for detection and collection. The $75 \%$ effluents were collected in capillary tubes. When at least $0.1 \mathrm{mg}$ had been obtained for each peak, and after purification on small Florisil columns, the molecular weights and fragmentation patterns were determined by mass spectroscopy. For the identification of unsaturated fatty acidmethyl esters, the method of Tinoco and Miljanich was applied (15) in which the esters are oxidized with permanganate in acetic acid.

\section{Free Fatty Acids in Cigarette Smoke}

The combined materials collected on the Cambridge filter and cold traps were tagged with trace amounts of stearic acid-1- $\mathrm{C}^{14}$ and oleic acid-9,10- $\mathrm{H}^{3}$ and then extracted for four hours with benzene. From this point on, the method for the fatty acid analysis is identical with that described in part $B$.

For each fatty acid analysis, $2 \times_{10}$ cigarettes were smoked. We found an experimental deviation of $\pm 7 \%$ for the five major acids. When the cigarettes to be smoked are selected not only by weight but also by draw resistance, the analysis can be accomplished within the same experimental deviation with $2 \times 3$ cigarettes.

- All light fixtures in the laboratories were covered with yellow plastic sheets to prevent irradiation by light below $470 \mathrm{m \mu}$ (12). 
Prior to establishing the actual determination of fatty acids in tobacco and its smoke, a method had to be worked out that permitted a quantitative extraction of the free fatty acids without hydrolyzing fatty acid esters. Figure $I$ represents a graphic summary demonstrating that $\mathbf{n}$-hexane is unsuitable for the quantitative extraction of fatty acids from tobacco, although it has been used for qualitative work (14). The extraction with benzene:ethanol $(4: 1)$ is also unsuitable since it brings about increasing yields of extractable acids and thus indicates the possibility of ester hydrolysis. With benzene, however, we found that the extraction was quantitatively accurate after 12 hours and remained stabile even after 36 hours. We have, therefore, chosen to standardize the procedure with 24-hour extractions with benzene.

The addition of methyl oleate- $1-\mathrm{C}^{14}$ to tobacco revealed only insignificant hydrolysis during the extraction and separation of the acids by $2 \mathrm{~N} \mathrm{KOH}$. We recovered in the neutral portion of the extract more than $98 \%$ of the unchanged ester. The acidic portion was practically free of components with $\beta$-activity. The $1-2 \%$ which were not recovered represent the expected loss during such procedure, as shown by blind tests. This result eliminated the need for a correcting factor for the quantitative analysis of free nonvolatile fatty acids in cigarette smoke.

The methylation of the free fatty acid concentrates with diazomethane resulted not only in methyl esters but also in a polymerization product of the alkylating agent (9). This newly

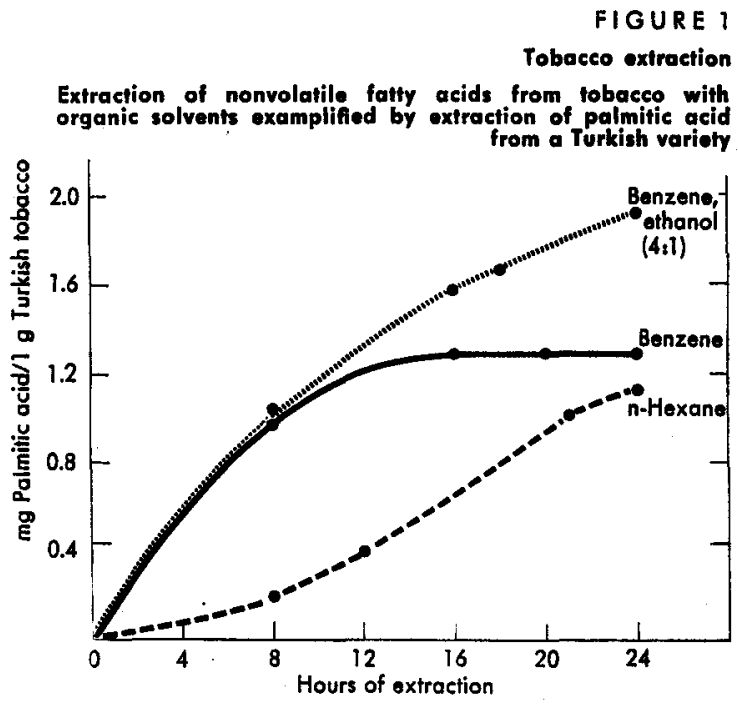
formed material interfered with the gas chromatogram of the higher fatty acids. $\mathrm{BF}_{3}$ was unsuitable as a methylating agent because it requires reflux-distillation of the acid concentrates in methanol; furthermore, the use of this method was found to be of limited value (6). 2,2-Dimethoxypropane (DMP) proved to be the most suitable methylating agent for the fatty acids. At room temperature DMP decomposes only into the volatile products methanol and acetone.

A gas chromatogram of the methyl esters of the nonvolatile free fatty acids from blended tobacco is presented in Figure 2. The unsaturated fatty acid esters of the concentrate are decomposed by oxidation and the remaining esters compared with the original fraction (Fig. 3). The identification of the individual peaks was based on retention times and infrared absorption spectra of the corresponding effluents. For the determination of unknowns, the molecular weights were determined by mass spectrometry. Since we did not separate the isomers of the fatty acid esters, the decomposition pattern in the spectra did not allow a differentiation between normal and methyl-branched isomers. According to Mold et al., the branched methyl isomers of the fatty acids amount to less than $10 \%$ and are not actually present in any appreciable amount with the possible exception of the 2-methyl isomers of $C_{18}$ acids and 3-methyl isomers of $C_{17}$ and $C_{19}$ acids (8). It is, furthermore, unknown to what extent these isomers derive from saturated and/or unsaturated fatty acids and a verification of these facts is quite cumbersome. We, therefore, hold the view that a differentiation between normal and methyl-

Chromalography of methyl esters of nonvolatile fatty acids This concentrafe was obtained by methylation of the acidic portion of a U. S. cigarette tobacco blend. The ordinate represents the relative defector response, the abscissa the The first figure at each peak represents the corbon number of the corresponding fatty acid, the figure after the colon indicates the number of double bonds for the compound.

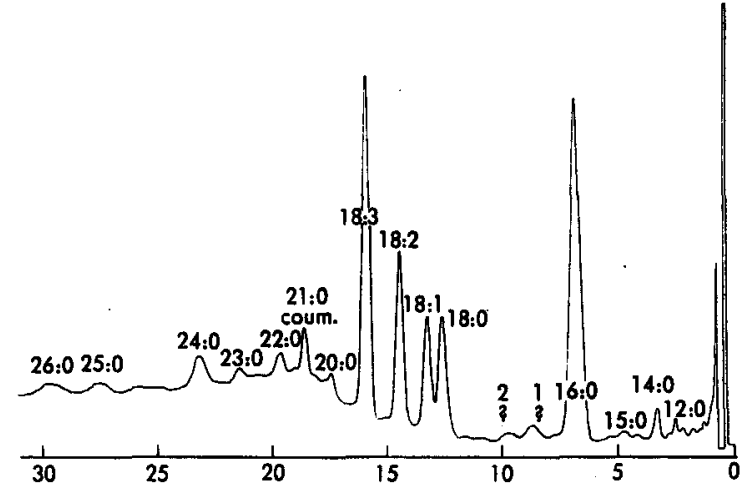




\section{FIGURE 3}

Chromatography of methyl esters of nonvolatile fatty acids

Upper curve: Concentrate of methyl esters obtained from acidic portion of a U. S. cigarette tobocco blend.

Lower curve: Same material after removal of unsaturated fatty acids by For details on curves, see legend for Fig. 2.

branched fatty acid isomers is not warranted at this time. However, of greater importance to bioassays is that no difference is known between the isomers of fatty acids as tumor promotors on mouse epithelium $(5,11)$.

The results of the analysis of six cigarette tobaccos are summarized in Table 1 and show the highest over-all free acid concentration for one Turkish variety with $0.6 \%$, then Bright tobacco, the cigarette blend, the second Turkish variety, Maryland, and Burley tobacco follow with $0.43,0.28,0.27,0.14$, and $0.09 \%$ respectively. These data indicate a higher concentration of free nonvolatile fatty acids in flue-cured and sun-cured tobacco than in air-cured tobaccos.

In addition to the seven major fatty acids in tobacco, $C_{12}$,

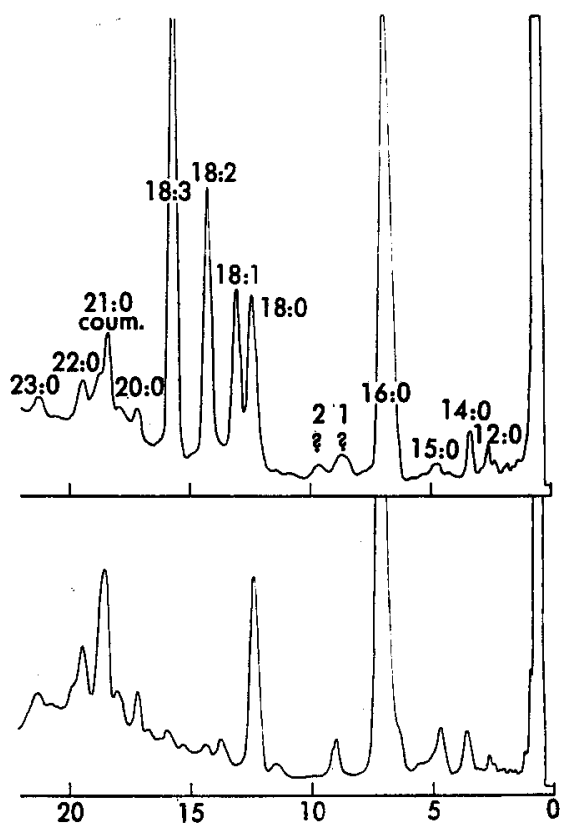
$C_{14}, C_{15}$ and all saturated acids between $C_{20}$ and $C_{26}$ were identified. The configurations of two components indicated by maxima in the gas chromatograms have so far not been determined. The two Turkish and Bright varieties as well as the United States tobacco blend gave one chromatographic peak which was identified as coumarin by mass and ultraviolet absorption spectra. One may assume that this aromatic lactone is originally present in tobacco.

Figure 4 shows a gas chromatogram of the methyl esters of the nonvolatile fatty acids from cigarette smoke. Table 2 contains the data for the five major acids in the smoke of cigarettes made exclusively from one sample each of Turkish, Bright, Maryland, and Burley tobacco, and a United States tobacco blend. Qualitatively, the fatty acids found in the smoke agreed with those from the tobacco extract. The sum of the five major nonvolatile fatty acids in the smoke of $1 \mathrm{~g}$ tobacco varied between $0.96 \mathrm{mg}$ for the Turkish variety and $0.21 \mathrm{mg}$ for the Burley sample. This amounts to about $1.05-2.6 \%$ of the wet particulate matter or a concentration at least four times that found in tobacco. Although the TPM yields for Bright and Burley cigarette tobacco are comparable with the data reported by Bellin (I), the two studies vary significantly in the nonvolatile free fatty acid content of the TPM. Bellin reported $5.7-5.9 \%$ for the "tar" of Bright tobacco and 4.5-5.1\% for the "tar" of Burley tobacco. Our values were $1.95 \%$ and $1.05 \%$ and demonstrate also a significant difference in the yields of the five major nonvolatile fatty acids in the mainstream smoke of different cigarette tobaccos (Table 2). This latter significant difference indicates, as to be expected, that the yields of fatty acids in the smoke are dependent on the concentration of fatty acids in the original tobacco.

The recovery rate of fatty acids from tobacco smoke condensate and tobacco extract was found to be better than $80 \%$.

FIGURE 4

Chromatography of methyl esters of nonvolatile fatty acids

Concentrate wos obtained by methylation of acidic portion of the smoke condensate of $16 \mathrm{U}$. S. blended cigarettes. For details on curves, see legend for Fig. 2.

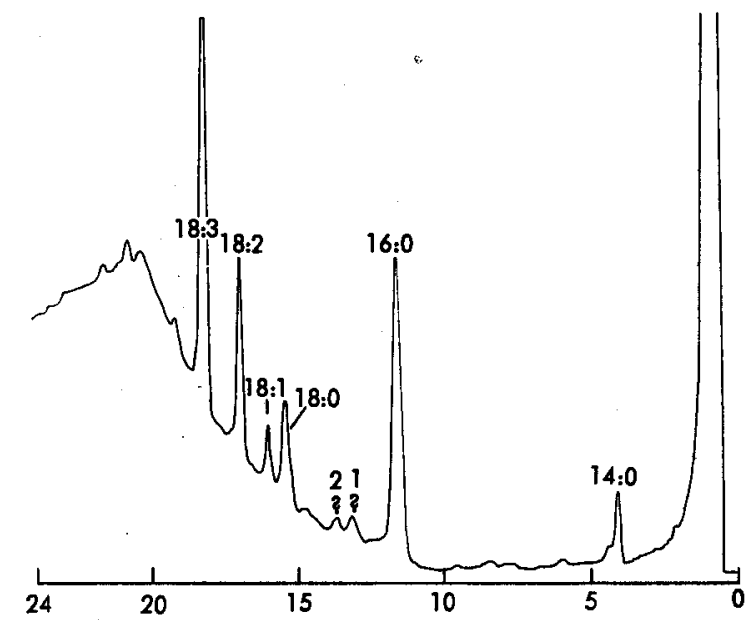




\begin{tabular}{lr|cccccc}
\hline \multicolumn{8}{c}{$\mu \mathrm{g} / 1 \mathrm{~g}$ Tobacco* } \\
\hline Acid & Turkish I & Turkish II & Bright & $\begin{array}{c}\text { Mary- } \\
\text { land }\end{array}$ & Burley & Blend \\
\hline Myristic & 220 & 150 & 65 & Trace & - & 180 \\
Palmitic & 1,480 & 530 & 930 & 420 & 220 & 530 \\
Palmitoleic & 300 & 160 & Trace & - & - & Trace \\
Stearic & 520 & 480 & 330 & 180 & 110 & 280 \\
Oleic & 480 & 220 & 230 & 110 & 70 & 220 \\
Linoleic & 880 & 320 & 610 & 250 & 180 & 420 \\
Linolenic & 2,120 & 870 & 2,130 & 420 & 360 & 1,160 \\
\hline TOTAL & 6.0 & 2.73 & 4.3 & 1.38 & 0.94 & 2.79 \\
mg/1 g & & & & & & & \\
\hline
\end{tabular}

- Dried tobacco; moisture content between 0.5-1.0\%.

TABLE 2

Free fatty acids in cigarette smoke

\begin{tabular}{l|r|r|r|r|r}
\hline \multicolumn{7}{c}{$\mu \mathrm{g} / 1 \mathrm{~g}$ Tobacco smoked * } \\
\hline \multicolumn{1}{c}{ Acid } & Turkish I & Bright & Maryland & Burley & Blend \\
\hline Palmitic & 284 & 197 & 107 & 55 & 152 \\
Stearic & 90 & 74 & 43 & 33 & 75 \\
Oleic & 108 & 39 & 32 & 21 & 58 \\
Linoleic & 146 & 113 & 52 & 50 & 96 \\
Linolenic & 329 & 310 & 66 & 52 & 240 \\
\hline TOTAL (mg) & 0.96 & 0.73 & 0.30 & 0.21 & 0.62 \\
Wet TPM (mg) & 37.2 & 37.6 & 26.4 & 20.1 & 32.3 \\
5 fatty acids & & & & & \\
\% of TPM (wet) & 2.6 & 1.95 & 1.14 & 1.05 & 1.9 \\
\hline
\end{tabular}

- Moisture content of the tobaccos varied between 11.5 and $12.0 \%$.

TABLE 3 Transfer to smoke of nonvolatile fatty acids*

\begin{tabular}{l|c|c|c|c|c}
\hline \multicolumn{6}{c}{ Cigarette tobacco } \\
\hline \multicolumn{1}{c|}{ Acid } & Turkish I & Bright & Maryland & Burley & Blend \\
\hline Palmitic & 21.4 & 23.5 & 28.3 & 27.4 & 31.7 \\
Stearic & 19.1 & 17.2 & 26.4 & 32.6 & 29.7 \\
Oleic & 26.9 & 18.5 & 31.6 & 33.7 & 29.1 \\
Linoleic & 18.4 & 20.5 & 22.9 & 29.4 & 25.2 \\
Linolenic & 17.2 & 16.2 & 17.3 & 16.0 & 23.0 \\
Average value & 17.8 & 19.1 & 24.1 & 24.8 & 24.6 \\
\hline
\end{tabular}

* Per cent recovery of free fatty acids in the mainstream smoke from $1 \mathrm{~g}$ cigarette tobacco burned. Moisture confent of the tobaccos varied between $11.5-12.0 \%$ 
Based on the assumption that the nonvolatile fatty acids in cigarette smoke derive exclusively from the corresponding acids in the tobacco, the transfer to the smoke varies between 16 and $34 \%$ (Table 3). As to be expected the lowest transfer rate was found for the highest unsaturated fatty acid, linolenic acid. Our data do not support the hypothesis that there exists a correlation between the yields in the smoke of fatty acids and particulate matter. As to be expected, the concentration of the free fatty acids in the tobacco represents a decisive factor for the yields of these components in the mainstream smoke. It is indicated, however, that tobacco with relatively high fatty acid concentrations, as Turkish and Bright tobaccos (6.0 and $4.3 \%)$, yield a lower transfer rate of these components into the mainstream smoke (17.8 and $19.1 \%$ ) than tobaccos with relatively low fatty acid concentration, such as Maryland and Burley tobaccos $(1.38$ and $0.94 \%$ ) resulting in higher transfer rates $(24.1$ and $24.8 \%)$. This observation appears to be independent of the TPM yield of the tobaccos.

\section{SUMMARY}

An analytical method was developed for the determination of nonvolatile free fatty acids in tobacco and tobacco smoke. Quantitative values were secured by employing stearic acid-1- $\mathrm{C}^{14}$ as internal standard for saturated acids, and oleic acid- $9,10-\mathrm{H}^{3}$ for unsaturated acids. The method yields exact values for the six major acids within $\pm 7 \%$ and can be applied as a micro method with as little as 10 to $20 \mathrm{mg}$ starting material.

The major free fatty acids in tobacco were found to be in order of decreasing concentration, linolenic, palmitic, linoleic, stearic, oleic, myristic, and palmitoleic acids. Further identified were $C_{12}, C_{14}, C_{15}$ and all saturated acids between $C_{20}$ and $C_{26}$. The concentrations of the acids in tobacco were found to vary between $0.6 \%$ and $0.09 \%$ in the six tested samples. Higher concentrations of these components were found in flue-cured and sun-cured tobaccos compared with air-cured tobacco. Coumarin was identified in the concentrated methyl esters of Turkish and Bright tobaccos as well as of the blended cigarette tobacco.

The analysis of cigarette smoke resulted qualitatively in a similar acid spectrum as found for tobacco. However, the concentration of the five major fatty acids was found to be at least four times higher in the particulate matter than in the original tobacco. Assuming that these fatty acids in the mainstream smoke derive from the acids originally present in tobacco, one finds a recovery rate of about $16-34 \%$.

These findings are of interest not only to the tobacco chemist but may have even broader implications because of the possible role that nonvolatile fatty acids play in the tumor promoting activity of tobacco smoke condensate.

ZUSAMMENFASSUNG

Die vorliegende Arbeit beschreibt eine Methode zur Bestimmung der gesättigten und ungesättigten Fettsäuren im Tabak und Tabakrauch. Zur Sicherung quantitativer Werte werden für gesättigte Säuren Stearinsäure-1- $\mathrm{C}^{14}$ und für ungesättigte Säuren Oelsäure-9,10- $\mathrm{H}^{8}$ als Markierungsverbindungen gewählt. Die experimentelle Fehlergrenze der Methode für die sechs Hauptverbindungen dieser Gruppe beträgt $\pm 7 \%$. Für die Analyse wurde weniger als $20 \mathrm{mg}$ Ausgangsmaterial benötigt.

Die Fettsäuren mit den höchsten Konzentrationen im Tabak sind Linolen-, Palmitin-, Linol-, Stearin-, Oel-, Myristin- und Palmitoleinsäuren. Außerdem wurden die acyclischen Säuren mit 12, 14 und 15 C-Atomen sowie alle gesättigten Fettsäuren mit 20 bis 26 C-Atomen identifiziert. Die Gesamtkonzentration der freien Fettsäuren in den sechs untersuchten Tabaken betrug zwischen 0,6 und $0,09 \%$. In den heißluftgetrockneten und sonnengetrockneten Tabaken lagen die Gesamtkonzentrationen dieser Säuren wesentlich höher als in den luftgetrockneten Tabaken. Mit den Fettsäuren wurde auch Cumarin im Türkischen und Virginia-Tabak sowie in der untersuchten amerikanischen Tabakmischung gefunden.

Die Cigarettenrauchanalyse auf freie Fettsäuren zeigte qualitativ ein vergleichbares Ergebnis mit der Analyse der entsprechenden Tabake. Quantitativ jedoch belaufen sich die Konzentrationen der freien Fettsäuren in den Rauchkondensaten auf mindestens das Vierfache verglichen mit den Kon- 
zentrationen in den ursprünglichen Tabaken. Nimmt man an, daß die freien Fettsäuren im Hauptstrom einer Cigarette nur von den freien Fettsäuren im Tabak stammen, dann ergibt sich eine Umsatzrate von 16 bis $34 \%$.

Einzelne freie Fettsäuren sowie die sauren Fraktionen der Tabakrauchkondensate haben sich als Tumorpromotoren auf der Mäusehaut erwiesen. Die vorliegenden Ergebnisse werden im Zusammenhang mit diesen Beobachtungen diskutiert.

RESUME

Une méthode analytique a été développée pour la détermination d'acides gras supérieurs libres dans le tabac et dans la fumée de tabac. Dans le but d'obtenir des résultats quantitatifs assurés sur les teneurs en acides gras libres saturés et non saturés du tabac et de sa fumée, on a utilisé respectivement comme standard interne l'acide stéarique $1^{-14} \mathrm{C}$ et l'acide oléique $9,10^{-3} \mathrm{H}$. Produisant des valeurs précises pour les six principaux composés de ce groupe, le procédé montre la limite d'erreur de $\pm 7 \%$. Il n'exige que 10 à $20 \mathrm{mg}$ de la matière de départ et peut donc servir à l'analyse micrométrique.

Les principaux acides gras libres trouvés dans le tabac sont les suivants (disposés dans l'ordre de concentrations descendantes): les acides linolénique, palmitique, linoléique, stéarique, oléique, myristique et palmitoléique. On a identifié, de plus, les acides acycliques $C_{12}, C_{14}, C_{15}$ et tous les acides gras saturés de $\mathrm{C}_{20}$ à $\mathrm{C}_{26}$. La concentration totale des acides gras libres dans les six échantillons de tabac analysés variait entre 0,6 et $0,09 \%$. Les concentrations totales des composés en question dans le tabac "air-cured" (séchage à l'air) se montraient nettement inférieures à celles trouvées dans les tabacs "flue-cured" (séchage à feu indirect) et »sun-cured" (séchage au soleil). La coumarine a aussi été identifiée dans les esters méthyliques concentrés des tabacs Virginia et turc ainsi que du tabac à cigarettes américain.

L'analyse de la fumée de cigarettes à l'égard de sa teneur en acides gras libres montrait un spectre qui, du point de vue qualitatif, ne différait que peu de celui produit par l'analyse du tabac. Les concentrations des cinq acides gras principaux se montraient, cependant, au moins quatre fois plus élevées dans la phase particulaire de la fumée que dans le tabac originaire. Supposé que les acides gras libres présents dans le flux principal de la fumée ne tirent leur origine que des acides gras libres du tabac, le taux de transfert va approximativement de 16 à $34 \%$.

Les observations expérimentales présentées offrent de l'intérêt non seulement aux chercheurs étudiant la chimie du tabac mais auront une portée encore plus étendue en considération du rôle promoteur possiblement joué par les acides gras supérieurs dans l'activité carcinogène du condensat de la fumée de tabac sur la peau de souris.

REFERENCES

1. Bellin, S. A.: 15th Tob. Chem. Res. Conf., Philadelphia, Oct. 1961.

2. Carruthers, W., and Johnstone, R. A. W.: Nature 184 (1959) 1131.

3. Clemo, G. R.: Tetrahedron 11 (1960) 11.

4. Hoffmann, D., and Wynder, E. L.: Cancer 13 (1960) 1062.

5. Holsti, P.: Acta Pathol. Microbiol. Scand. 46 (1959) 51.

6. Metcalfe, L. D., and Schmitz, A. A.: Anal. Chem. 33 (1961) 363.

7. Mohnachev, L., Serdynk, L., and Ivanov, N.: Compt. Rend. Acad. Bulgare Sci. 20 (1967) 445.

8. Mold, J. D., Means, R. E., and Ruth, J. M.: Phytochem. 5 (1966) 59.

9. Morrison, W. P., Lawrie, T. D. V., and Blades, J.: Chem. Ind. 1964, 1534.

10. Radin, N., Hajra, A. K., and Akahari, Y.: J. Lipid Res. I (1960) 250.

11. Saffiotti, U., and Shubik, P.: Natl. Cancer Inst. Monogr. 1o (1963) 489.

12. Schlenk, H., and Gellerman, J. L.: Anal. Chem. 32 (1966) 1412.

13. Schmeltz, I., and Schlotzhauer, W. S.: Tobacco Sci. 6 (1962) go.

14. Swain, A. P., and Stedman, R. L.: J. Assoc. Offic. Agr. Chemists 45 (1962) 536.

15. Tinoco, J., and Miljanich, P. G.: Anal. Biochem. 11 (1965) 548. 
16. Van Duuren, B. L., and Kosak, A. I.: J. Org. Chem. 23 (1958) 473.

17. Wartman, W. B., Cogbill, E. C., and Harlow, E. S.: Anal. Chem. 31 (1959) 1705.

18. Weissberger, A., Proskauer, E. S., Riddik, J. A., and Toops, E. E., Jr.: Technique of Organic Chemistry, Vol. II, Organic Solvents, Sec. Ed. 1955, Interscience Publ. Inc., New York.

19. Williamson, J. T., and Clark, P. J.: Beitr. Tabakforsch. 1 (1962) 187.

20. Wissenschaftliche Forschungsstelle im Verband der Cigarettenindustrie: Beitr. Tabakforsch. 1 (1961) 31 and 71.

21. Wynder, E. L., and Hoffmann, D.: Cancer 14 (1961) 1306.

22. Wynder, E. L., and Hoffmann, D.: Tobacco and Tobacco Smoke, Studies in experimental carcinogenesis, 1967, Academic Press, New York.

Authors' address:

Sloan-Kettering Institute for Cancer Research, Division of Environmental Cancerigenesis, 410 East 68th Street, New York, N. Y., 10021, USA 